\title{
Antarctic Research Strategy of Turkey
}

\author{
Ersan BAŞAR
}

\author{
Karadeniz Technical University, Faculty of Marine Sciences, Turkey \\ ebasar@ktu.edu.tr; ORCID ID: https://orcid.org/0000-0002-1458-4102
}

Nearly 95\% of Antarctica, the Earth's fifth-largest continent, is covered with ice. One of the unique characteristics of this amazing continent is that it is both the coldest and the highest region on Earth. The continent, with lots of mysteries and wonders yet to be discovered, has been home to many scientific studies throughout the world. The unknown facts of the continent are among the key points of the global climate change on our planet.

With a declaration of policy in 1957, The International Council of Scientific Unions has aimed to increase scientific research in the Antarctic region. Also known as the continent of science and peace, Antarctica is a region where scientific studies can be carried out freely, as well as transnational scientific cooperation boosts.

The Antarctic Treaty was signed in Washington in 1959 by 12 countries whose scientists had been active in and around Antarctica during the International Geophysical Year of 1957-1958. It entered into force in 1961 and has since been acceded to by many other nations. The total number of Parties to the Treaty is now 54. 29 of these countries are Consultative Parties, and 25 of them are Non-Consultative Parties. Turkey acceded to the Antarctic Treaty in 1995 and has been one of the Non-Consultative Parties to the Treaty since then. Consultative Parties are the ones with the right to vote at the meetings organized to make decisions about Antarctic issues.

Many scientists from various disciplines have travelled to the continent to conduct research activities for many years. The first Turkish scientist to visit Antarctica is Dr. Atok Karaali, who went there in 1959 and carried out some research on ionospheric physics. After that, Prof. Dr. Ümran İnan carried out studies on the upper atmosphere of Antarctica, and Prof. Dr. Serap Tilav carried out scientific studies in the continent in 1980 and 1991, respectively. Due to the contributions of these pioneering Turkish scientists to science in Antarctica, some geographical regions in the continent were named Karaali Rocks, Inan Peak and Tilav Cirque. It is also known that many other Turkish scientists have gone to the continent for scientific studies later on. Antarctic studies in Turkey continued with Turkey's 1st National Scientific Expedition to Antarctica, organized under the auspices of the Presidency of the Republic of Turkey in 2017. These expeditions have been carried out regularly since then and were named Turkish Antarctic Expedition (TAE) I, II, III, and IV, during which a total of more than 80 scientific projects from different subject areas were carried out. Setting out to contribute to earth science, Turkey has incorporated many international scientists into its expeditions as part of the National Polar Science Program teamed up in 2018. The outcomes of these expeditions have been presented to the scientific world in both scientific articles and project results to contribute to science in Antarctica in various disciplines.

In order to maintain the sustainability of the scientific studies carried out in Antarctica by ensuring their continuity, Turkey has initiated actions to establish the Turkish Scientific 
Research Base. With the TAE I and TAE II expeditions in 2017 and 2018, appropriate regions where Turkey could establish bases in Antarctica were determined through investigations. During the TAE II expedition in 2018, the first temporary science camp was established on Robert Island, and scientists consisting of 9 people carried out their studies on this island. In the TAE III expedition in 2019, a temporary Science Camp was established on Horseshoe Island, where the Science Base would be established. The actions to establish a Turkish Scientific Research Base in this region in the following years continued with the TAE IV expedition performed in 2020. Turkey still continues actions to establish bases with many studies in different areas. Turkey has also established a weather station on Horseshoe Island and the surrounding islands, including 3 Global Navigation Satellite System (GNSS) stations. Instant data are obtained from some of these stations, and these data are shared with scientists from other countries.

Antarctica, where studies in different disciplines are carried out, attracts scientists' attention. Turkey collaborates with scientists from other countries by increasing scientific research and bilateral cooperation in the continent. Turkey also gives importance to establishing a permanent scientific base in Antarctica by increasing the scientific studies and science expeditions made regularly every year. In parallel with these studies, it is about to have a say in the continent's future by moving from the position of Non-Consultative Parties to Consultative Parties in Antarctica.

Considering the international policies that Turkey has developed recently, it is seen that Poles are in the centre of interest. The factors that emphasize the importance of polar studies are new perspectives on climate change, energy policy, and scientific studies. 


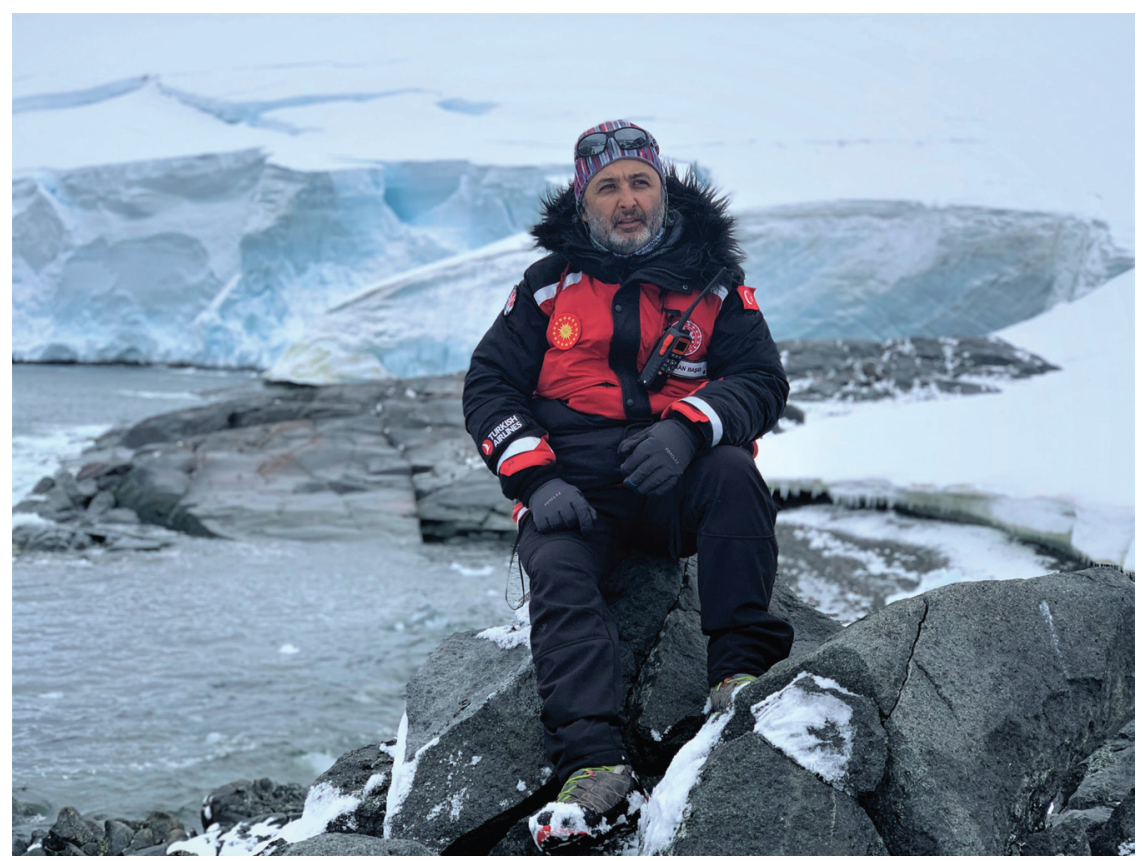

\section{Prof. Dr. Ersan BAŞAR}

Mr. Başar works as a Professor in the Department of Maritime Transportation and Management Engineering at Karadeniz Technical University. In 2003, he defended his doctoral dissertation titled "Temporal and Spatial Distribution of Oil Spill after Tanker Accidents in the İstanbul Strait." After this study, he carried out studies on ship accidents and subsequent marine pollution in the Black Sea and the Turkish Straits System. He has many scientific publications on risk determination in ship accidents, oil pollution, and emergency management. Besides, he did post-doctoral studies at British Columbia University in Canada in 2005, where he carried out research on oil-spill and emergency response methods at sea.

Mr. Başar participated in Turkish Antarctic Expeditions I, II, III, and IV organized in 2017-2020, during when he carried out scientific projects on marine pollution. In addition, he served as the camp leader in the TAE II expedition and as the expedition leader in the TAE IV expedition. He has been to the Antarctic continent four times as well as an expedition to the Arctic. He carried out scientific projects during those expeditions.

Mr. Başar, who has broad experiences on life and survival in nature, has been the Head of the Turkish Mountaineering Federation since 2016 and speaks English and Russian. 